\title{
High Sensitivity C-Reactive Protein in Professorsfrom Mexicali, BC Mexico
}

\author{
Josefina Ruiz Esparza C ${ }^{*}$, Octavio Robinson Navarro ${ }^{1}$, Raúl Díaz Molina ${ }^{1}$, E. Grabriela Carrillo Cedillo
}

${ }^{1}$ School of Medicine Mexicali, Autonomous University of Baja California, México.

${ }^{2}$ Science and Engineering Faculty, Autonomous University of Baja California, México.

\author{
Received Date: May 23, 2015 \\ Accepted Date: June 17, 2015 \\ Published Date: June 22, 2015
}

Corresponding author: Esparza, C. J. R.School of Medicine Mexicali, Autonomous University of Baja California, México.Tel: (686) 5571622 ext 123; E-mail:josefinaruizesparza@uabc.edu.mx

Citation: Esparza, C. J. R., et al.High Sensitivity C-Reactive Protein in Professors from Mexicali, BC Mexico (2015) J Food Nutr Sci 2(1): 76-78.

Keywords: High sensitivity C-reactive protein; BMI; chronic non-communicable diseases

\begin{abstract}
High sensitivity C-reactive protein (hsCRP) is a biomarker whose concentration, in normal conditions, should be lower than $1 \mathrm{mg} / \mathrm{L}$; otherwise it is associated with non-communicable diseases (NCDs). The aim of the study was to find out the hsCRP concentration in apparently healthy professors and how it relates to age and BMI. It was a cross-sectional design, with a sample of 72 university professors. A clinical and anthropometric assessment and quantification of hsCRP through an enzyme immune assay (EIA) method was performed. The average in our study sample was $49.75 \pm 10.05$ years, with BMI median of 26.15; IQR $23.45,29.11 \mathrm{~kg} / \mathrm{m}^{[1,2]}$. The hsCRP concentrations of all participants was $3.87(2.33,6.55) \mathrm{mg} / \mathrm{L}$. The sample selected according to the criteria presented a median of 1.66; IQR $0.97,3.52 \mathrm{mg} / \mathrm{L}$. The hsCRP was directly and significantly correlated with BMI and age. The median of the hsCRP concentration in the study group was above reference values. It is important to point out that our study sample were professors who appeared to be in good health, and could therefore be associated with the emerging development of an inflammatory process and the risk of suffering NCDs.
\end{abstract}

\section{Introduction}

High sensitivity C-reactive protein (hsCRP)is a biomarker whose concentration in normal conditions must be lower than $1 \mathrm{mg} / \mathrm{L}^{[1,2]}$. Ridker et al have proposed a low-, medium- and high- risk classification for concentrations lower than $1 \mathrm{mg} / \mathrm{L}$, from one to three $\mathrm{mg} / \mathrm{L}$ and from three to ten $\mathrm{mg} / \mathrm{L}$ respective$1 y^{[3,4]}$. One method used to quantify it is the enzyme immunoassay(EIA), developed for hsCRP1.Another method is based on automated immunoassay, using the Dade-Behring Nephelometer, implemented in Germany in 1996 and is used in Europe and other countries ${ }^{[3]}$.

One characteristic of this protein is that its concentration in serum remains stable for several years ${ }^{[5]}$, which promotes associating it with early development of subclinical and asymptomatic inflammatory processes, which in turn are related to the development of chronic noncommunicable diseases (NCDs) ${ }^{[6,7]}$, such as cardiovascular diseases (CVD) ${ }^{[8,9]}$, type 2 diabetes mellitus (DM2), metabolic syndrome (SM) ${ }^{[10]}$ and obesity ${ }^{[11]}$.

On the other hand, the said conditions account for one fourth of deaths worldwide, according to reports by the World Health Organization (WHO ${ }^{[12]}$. HsCRP appears to be related to lifestyle, diet and body weight. Increase in body mass index (BMI) to values indicating obesity, smoking and age were linked to a higher concentration of hsCRP ${ }^{[6,13]}$. The aim of this study was find out the concentration of hsCRP in a sample of apparently healthy college professors and how it relates to age and BMI.

\section{Methodology}

It was a cross-sectional design. The study included fulltime professors of the Autonomous University of Baja California (UABC), Mexicali campus, apparently healthy, with no clinical diagnosis of any disease, evaluated by a physician. The participants, whose hsCRP concentration was greater than $10 \mathrm{mg} / \mathrm{L}$, were not included. The sample size was 72 professors, male and female. This project was approved by The Bioethics Committee of the Medicine School, and the study group provided informed consent to participate in the study.

A clinical evaluation was done on the study group, which included medical history at least three readings of diastolic blood pressure (DBP) and systolic blood pressure (SBP) were taken at intervals of $5 \mathrm{~min}$ the person had been seated. The anthropometric assessment included measurements of weight, height, and waist circumference using standardized anthropometric techniques ${ }^{[11]}$. In addition, percentage of body fat was measured using the Bioelectric Impedance Analysis (BIA) RJL System, model Quantum II (RJL Systems Inc., USA). Age, gender and height of the study group were fed in the BIA machine to generate a report that included an individual's BMI and body

Copy rights: (C2015 Esparza, C. J. R. This is an Open access article distributed under the terms of Creative Commons Attribution 
fat percentage, among other data ${ }^{[14]}$.

To quantify the hsCRP, venous blood samples were drawn from fasting subjects, and collected into EDTA-containing tubes; each vial was identified with the professor's employee number, and kept in a cooler for transportation to the lab. Biologic disposable material such as syringes and cotton were placed in a red bag, following the guidelines for biologic residue disposition and procedure manual of the Faculty. The samples were centrifuged to obtain serum, which was frozen until the complete batch of sample was obtained. All the samples were analyzed for the quantification of the hs-CRP using hs-CRP Accusing ELISA Kit (Monobind Inc., Lake Forest, CA, USA). This technique is based on the detection of an immobilized antigen on a solid phase through antibodies that directly or indirectly generate a reaction whose colorful product outcome can be measured spectrophotometrically ${ }^{[15]}$.

Statistical analysis was performed using the SPSS version 18.0. Means ( \pm SD) were calculated for the characteristics of the study group. Non-parametric analysis was performed for, the variables that were not distributed normally according to the Kolmogorov-Smirnov test, and expressed as median and interquartile ranges (IQR). The data was tested at the value of $\mathrm{P}<0.05$ for statistical significance.

\section{Results}

The sample with average age of $49.75 \pm 10.05$ years, presented a median BMI of 26.15; IQR 23.45, $29.11 \mathrm{~kg} / \mathrm{m}^{2}$. The hsCRP concentration was 3.87; IQR 2.33, $6.55 \mathrm{mg} / \mathrm{L}$. A $4.3 \%$ of this sample presented a serum concentration of hsCRP above $10.0 \mathrm{mg} / \mathrm{L}$; therefore they were excluded from the study. In the final sample of 72 participants, a median hsCRP of 1.66; IQR $0.97,3.52 \mathrm{mg} / \mathrm{L}$ was found. Among them, 25\% presented hsCRP concentrations under one $\mathrm{mg} / \mathrm{L}$ and $75 \%$ between 1 and $10 \mathrm{mg} / \mathrm{L}$.

The data by gender is presented in Table 1, where a median hsCRP concentration of 1.68; IQR $0.61,3.18 \mathrm{mg} / \mathrm{L}$ was found in male. Female presented an hsCRP concentration of 1.67; IQR 1.03, 3.11 mg/L. Median systolic blood pressure (SBP) was 120; IQR 115, 124 and 120: IQR 110, $130 \mathrm{mmHg}$ for men and women, respectively. Median diastolic blood pressure was 80; IQR 74, 90 and 68; IQR 62, $80 \mathrm{mmHg}$ in men and women, respectively.

Table 1: Clinical characteristic of the study participants.

\begin{tabular}{|c|c|c|c|}
\hline & Men Median (IQR) & Women Median (IQR) & $\mathrm{p}$ \\
\hline hsCRP $(\mathrm{mg} / \mathrm{L})^{\circ}$ & $1.68(0.61,3.18)$ & $1.67(1.03,3.11)$ & 0.005 \\
\hline Age (years) & $47.08 \pm 11.46$ & $47.79 \pm 9.83$ & 0.53 \\
\hline SBP $(\mathrm{mmHg})$ & $120.00(115.00,124.00)$ & $120.00(110,130)$ & 0.514 \\
\hline DBP $(\mathrm{mmHg})^{\circ}$ & $80.00(74.00,90.00)$ & $68.00(62.00,80.00)$ & 0.017 \\
\hline Height $(\mathrm{m})^{\circ}$ & $1.73(1.69,1.77)$ & $1.61(1.57,1.65)$ & 0.001 \\
\hline Weight $(\mathrm{kg})^{*}$ & $81.72 \pm 14.15$ & $71.13 \pm 13.51$ & 0.001 \\
\hline WC $(\mathrm{cm})^{\circ}$ & $97.00(92,105)$ & $85.00(80.75,97.00)$ & 0.001 \\
\hline Hc $(\mathrm{cm})$ & $105.5(102.50,108.50)$ & $102.25(99.75,112.5)$ & 0.260 \\
\hline BMI $\left(\mathrm{kg} / \mathrm{m}^{2}\right)$ & $28.01(25.90,29.19)$ & $25.73(22.18,32)$ & 0.106 \\
\hline BIA $(\%)$ & $28.80(24.00,32.00)$ & $31.30(26.80,37.00)$ & 0.001 \\
\hline $\mathrm{n}=72$ & $46.9 \%$ & $53.10 \%$ & \\
\hline
\end{tabular}

* media \pm standard deviation, significant difference $\mathrm{P}<0.05$; IQR Interquartile range; BMI, Body mass index; SBP: systolic blood pressure. DBP: Diastolic blood pressure. WC: Waist circumference. Hc: Hip circumference. BIA: Bioelectric impedance analysis, $\%$ of body fat.

${ }^{\circ}$ median (interquartile ranges)

Median BMI for men was 28.0; IQR25.90, $32.00 \mathrm{~kg} /$ $\mathrm{m}^{2}$, while for women it was 25.73; IQR22.18, $29.19 \mathrm{~kg} / \mathrm{m}^{2}$. Both genders displayed excess weight, and obesity in the high IQR according to BMI data. On the other hand, there was a direct and significant correlation between hsCRP and BMI in the study sample, as can be observed in Figure 1.

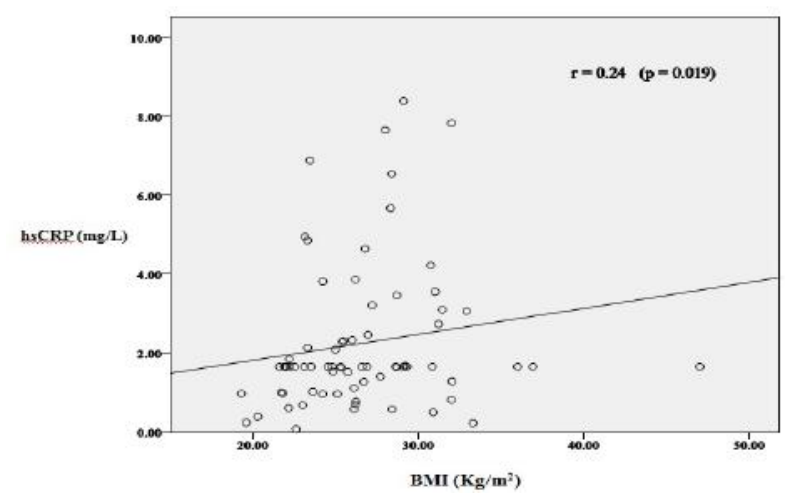

Figure1: Correlation analysis between participants' hsCRP and BMI.

When the concentration of hsCRP was linked to age, a direct and significant correlation was discovered in addition to the correlation coefficient $r$ of 0.026 , as can be observed in Figure2.

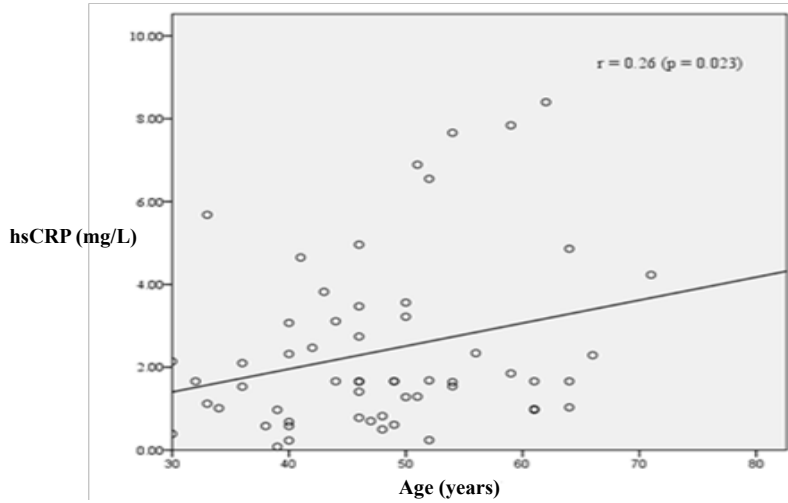

Figure 2: Correlation analysis between hsCRP and age of study group.

\section{Discussion}

The median of hsCRP serum concentration in the total sample of participants was 3.87; IQR 2.33, $6.55 \mathrm{mg} / \mathrm{L}$ which was higher than the one reported for a Latin population ${ }^{[16]}$ with similar BMI and age as the present study, whose median was 2.5; IQR 2.18, $2.86 \mathrm{mg} / \mathrm{L}$. Similarly data obtained from research that reported hsCRP levels ranging from 1.7 to $3.2 \mathrm{mg} / \mathrm{L}$ of hsCRP ${ }^{[17]}$ was lower to the hsCRP levels found in the present study (median of 2.26; IQR 1.11, $6.68 \mathrm{mg} / \mathrm{L}$ ). This difference is probably due to the fact that said population was 10 years younger than ours, even though BMI was similar.

It should be pointed out that, of the sample selected for this research, only $25 \%$ of the professors presented hsCRP concentrations within the reference values, which indicated that the rest could be in an initial subclinical and asymptomatic stage of some inflammatory processes, like NCDs, mainly CVDs, DM2, Alzheimer, and some types of cancer ${ }^{[18]}$. On the other hand, age 
presented direct relation to hsCRP, similar data reported in another investigation $^{[19]}$.

\section{Conclusions}

The median hsCRP concentration of the study group was above reference values. It is important to point out that the present study sample included professors who were apparently healthy, and could thus be related to the incipient development of an inflammatory process and the risk of suffering NCDs.

These results could improve the quality of prevention programs in health institutions; the population could have better quality of life, and institutions could cut expenses earmarked for the corresponding health complications.

\section{References}

1. Macy, E.M., Hayes, T.E., Tracy, R.P. Variability in the measurement of C-reactive protein in healthy subjects: implications for reference intervals and epidemiological applications. (1997) Clin Chem 43(1):52-58. 2. Review criteria for assessment of C-reactive protein (CRP), high sensitivity C-reactive protein, and cardiac C-reactive protein (cCRP) assays. (2005) US Food and Drug Administration.

3. Rifai, N., Tracy, R.P., Ridker, P.M. Clinical efficacy of an automated high-sensitivity C-reactive protein assay. (1999) Am Assoc Clin Chem 45(12):2136-2141.

4. Ridker, P.M., Buring, J.E., Cook, N.C., et al. C-reactive protein, the metabolic syndrome and risk of incident cardiovascular events: an 8-years follow-up 14719 initially healthy American woman. (2003) Circulation 107(3): 391-397.

5. Pepys, M.B., Hirschfield, G.M. C-reactive protein: a critical update. (2003) J Clin Invest 111(12):1805-1812.

6. Galland, L. Diet and Inflammation. (2010) Nutr Clin Pract 25(6): 634-640.

7. Brito, V. A., Alcaraz, F., Augustovski, A., et al. High sensitivity C protein as an independent risk factor in people with and without history of cardiovascular disease. (2015) Arch Cardiol Mex 85(2): 124-135.
8. Dallmeier, D., Koenig, D. Strategies for vascular disease prevention: the role of lipids and related markers including apolipoproteins, low-density lipoproteins (LDL)-particle size, high sensitivity C-reactive protein (hs-CRP), lipoprotein-associated phospholipase A2 (LpPLA(2)) and lipoprotein(a) (Lp(a)). (2014) Best Pract Res Clin Endocrinol Metab 28(3): 281-294.

9. de Carvalho Vidigal, F., Ribeiro, A. Q., Babio, N., et al. Prevalence of metabolic syndrome and pre-metabolic syndrome in health professionals: LATINMETS Brazil study. (2015) Diabetology\&metabolic síndrome 7(1): 1-9.

10. Tehrani, D. M., Gardin, J. M., Yanez, D., et al. (2013). Impact of inflammatory biomarkers on relation of high density lipoprotein-cholesterol with incident coronary heart disease: cardiovascular Health Study. Atherosclerosis 231(2): 246-251.

11. Shaharyar, S., Roberson, L. L., Jamal, O., et al. Obesity and metabolic phenotypes (metabolically healthy and variants) are significantly associated with prevalence of elevated $\mathrm{C}$ - reactive protein and hepatic steatosis in a large healthy Brazilian population. (2015) J Obes.

12. Cardiovascular diseases (CVDs). (2015) WHO.

13. Serrano, M., Morte, S., Alvarez, V., et al. The inflammatory process of cardiovascular disease: new markers. (2001) An Sist Sanit Navar 24(3): 315-326.

14. Aparicio, M.R., Estrada, L.A., Fernández, C., et al. Manual de Antropometría. (2004) CONACYT.

15. Hernández- Ramírez, D.F., Cabiedes, J. Immunological Techniques that Support the Diagnosis of the Autoimmune Diseases. (2010) Reumatol Clin 6(3): 173-177.

16. Shah, T., Newcombe, P., Smeeth, L., et al. Ancestry as a determinant of mean population $\mathrm{C}$-reactive protein values: implications for cardiovascular risk prediction. (2010) Cir Cardiovasc Genet 3(5): 436-444.

17. Flores, M., Barquera, S., Carrión, C., et al. Concentraciones de proteína $\mathrm{C}$ reactiva en adultos mexicanos: alta prevalencia de un factor de riesgo cardiovascular. (2007) Salud Pública Mex 49(3): S348-S360. 18. Jialal, I., Devaraj, S. Inflammation and atherosclerosis: the value of the high-sensitivity C-reactive protein assay as a risk marker.(2001) Am J Clin Pathol 116 Suppl: S108-S115.

19. Yamamoto, K., Okazaki, A., Ohmori, S. The relationship between psychosocial stress,age, BMI, CRP, lifestyle, and metabolic syndrome in apparently healthy subjects. (2011) J Physiol Anthropol 30(1):15-22.
Online ISSN: 2377-0619

Journal Title: International Journal Food and Nutritional Science Journal Short Name: Int J Food Nutr Sci
Ommega Online Publishers

E-mail: editor.foodscience@ommegaonline.com Website: www.ommegaonline.com 